IZA DP No. 9028

Clean Money in a Dirty System:

Relationship Networks and Land Rezoning in Queensland

Cameron K. Murray

Paul Frijters

April 2015 


\title{
Clean Money in a Dirty System: Relationship Networks and Land Rezoning in Queensland
}

\author{
Cameron K. Murray \\ University of Queensland \\ Paul Frijters \\ University of Queensland \\ and IZA
}
Discussion Paper No. 9028
April 2015

IZA

P.O. Box 7240

53072 Bonn

Germany

\author{
Phone: +49-228-3894-0 \\ Fax: +49-228-3894-180 \\ E-mail: iza@iza.org
}

\begin{abstract}
Any opinions expressed here are those of the author(s) and not those of IZA. Research published in this series may include views on policy, but the institute itself takes no institutional policy positions. The IZA research network is committed to the IZA Guiding Principles of Research Integrity.

The Institute for the Study of Labor (IZA) in Bonn is a local and virtual international research center and a place of communication between science, politics and business. IZA is an independent nonprofit organization supported by Deutsche Post Foundation. The center is associated with the University of Bonn and offers a stimulating research environment through its international network, workshops and conferences, data service, project support, research visits and doctoral program. IZA engages in (i) original and internationally competitive research in all fields of labor economics, (ii) development of policy concepts, and (iii) dissemination of research results and concepts to the interested public.
\end{abstract}

IZA Discussion Papers often represent preliminary work and are circulated to encourage discussion. Citation of such a paper should account for its provisional character. A revised version may be available directly from the author. 


\title{
ABSTRACT \\ Clean Money in a Dirty System: Relationship Networks and Land Rezoning in Queensland
}

\begin{abstract}
We use a unique regulatory event that occurred in Queensland, Australia, from 2007- 2012, to examine the predictive power of landowner relationship networks and lobbying behaviour on successfully gaining value-enhancing rezoning. A State authority, the Urban Land Development Authority (ULDA), took planning control away from local councils in selected areas in order to increase the speed and scale of development in those areas, in the process increasing land values. Using micro-level relationship data from multiple sources, we compare the relationship-network characteristics of landowners of comparable sites inside and outside the ULDA areas, finding that 'connected' landowners owned $75 \%$ of land inside the rezoned areas, and only $12 \%$ outside, capturing $\$ 410$ million in land value gains out of the total $\$ 710$ million from rezoning. The marginal gains to all landowners of becoming connected in our sample were $\$ 190$ million. We also find that engaging a professional lobbyist is a substitute for having one's own connections. Scaling up from our sample of six rezoned areas to the hundreds of rezoning decisions across Queensland and Australia in the last few decades, suggests that many billions of dollars of economic rent are being regularly transferred from the general population to connected land owners through political rezoning decisions.
\end{abstract}

JEL Classification: D72, D73, R52, R58

Keywords: networks, social capital, rezoning, corruption, lobbying

Corresponding author:

Paul Frijters

University of Queensland

Level 6, Colin Clark Building (39)

St Lucia, Brisbane, Qld 4072

Australia

E-mail: p.frijters@uq.edu.au 


\section{Introduction}

Land rezoning involves two distinct decisions, one is to rezone more land to be higher-density and the second is the precise area where new planning rules apply. Political pressure to expand higher value zoning areas is usually argued to come from owners of undeveloped land who directly benefit, in concert with a wide range of secondary beneficiaries who live in the wider region, such as banks and construction companies, in a type of 'growth coalition' (Molotch, 1976, Terhorst \& Van De Ven, 1995, Strom, 1996, Grabowski, 2013). The secondary decision, where exactly to rezone, involves the allocation of property rights from the community to the owners of the land within the rezoning boundary at the moment of rezoning. In the absence of mechanisms such as land value taxes or betterment taxes that recoup the value of the resulting price-differential, there is scope for bargaining between politicians and land owners of different areas, including the potential for corruption and bribery during the final determination of rezoning boundaries.

We study this secondary decision in Queensland, Australia, where we look at how relationship networks are used by property developers to influence rezoning boundary decisions to their advantage. Using an event study that capitalises on the long delay between the expressed political intention to rezone land and the precise drawing of the boundaries, we are able to unpack the political drivers of rezoning area decisions quite apart from the general political decision to rezone as a growth imperative 1 It turns out that during the interval between the decision to instigate rezoning and the final decision to rezone specific areas, proposed rezoning borders change substantially. We look at the ex post rezoned boundaries, and compare the land owners inside the boundary with land owners immediately outside the boundary, which are often adjoining properties. Our analysis shows that well-connected property developers buy up land on the urban fringe and then use their political connections to ensure their land falls within final rezoned areas, while excluding neighbouring lots belonging to others, leading to quite oddly shaped rezoned areas that would seem to make little economic sense.

Our method is to combine longitudinal data on land plots and their value with data on the connections between land owners and a large set of entities involved in rezoning. Our relationship network comprises corporate ownership and directorship connections of land owners and their companies; connections from employing professional lobbyists; property industry group membership; and many other connection types, such as employing professional lobbyists. We uncover marked differences in the networks of the successful property developers and the unsuccessful ones. We thus test the idea of several economists and sociologists that social relationships provides the capacity to sustain the implicit exchange of favours which could not otherwise be achieved (Sobel, 2002, Jackson et al. 2012, Coleman, 1990, Burt, 2000, Granovetter, 2005). Those with advantageous positions in relationship networks are able to get preferential treatment precisely because of their ability to be involved in implicit dealings that take advantage of a missing formal market in political favours. This adds to the literature on urban development and zoning decisions, where very little is currently known about the role of such relationship networks in rezoning decisions, though the role of relationships has been widely argued to be important (Simon \& Henneberry, 2000; Calabrese et al. , 2007, Solé-Ollé \& Viladecans-Marsal, 2012; Dehring et al. 2008; Hilber \& Robert-Nicoud, 2013; Engle et al. , 1992, Solé-Ollé \& Viladecans-Marsal, 2013).

\footnotetext{
${ }^{1}$ Our paper mainly relates to the urban planning literature on political determinants of planning decisions, particularly event studies of political favouritism (Lubell et al. $\mid 2005$ De Figueiredo \& Richter 2013 Calabrese

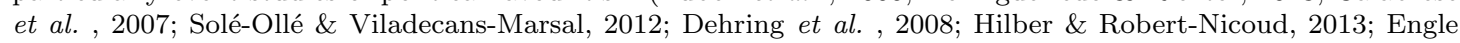

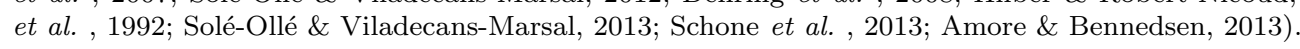


Using historical sale price data, we calculate the implicit transfer from the community to these favoured connected property developers to be $58 \%$ of the $\$ 710$ million of improved land value of the rezoning, which they received by owning $75 \%$ of the rezoned areas, implying that very little of the price benefits of rezoning goes to the general public. At the margin, the value gains to all property holders from becoming connected were $\$ 190$ million. When scaled up from our sample to the national level, these results suggest that each year many billions of value gains are being redirected toward well connected land owners at the expense of the unconnected, which includes the general public that has the ex ante property rights over the rezoning decisions.

Whilst we do not directly observe the quid pro quo aspect within these relationship networks (apart from the publicly available political party contributions, which are relatively small), there have been many criminal cases and scandals that are informative about that quid pro quo. Several high-profile cases document how the property developers are often direct family members of the politicians involved ${ }^{2}$ or how the politicians, either before they run for office or once out of office, join property developers as directors or co-owners (Dodson et al., 2006 ).

The picture that emerges from our analyses is that property development and rezoning is one of the biggest rent-seeking activities for local and State politics in Queensland, with a small set of connected property developers getting the lion's share of the new property rights from rezoning, in a process involving politicians from both the major political parties over long periods of time. This favours a view of political rent-seeking as a process of entrenchment of insiders who are well-informed and well-connected to the bureaucratic procedures and work the system to their mutual advantage at the expense of outsiders. For instance, simply being connected to the main component of the relationship network in our sample increases the probability of being favourably rezoned by 19 percent, while a move from the minimal to maximal level of centrality in that network provides an additional 25 percent increase in rezoning probability. Employing a professional lobbyist increases this probability by 37 percent.

The paper proceeds as follows. Section 2 provides a brief summary of the related literature, followed by the institutional background to our event study in Section 3. Section 4 outlines our data and methods of analysis, with the results presented in Section 5. Section 6 discusses the result and potential policy options for pricing the political favors done in rezoning.

\section{Related Literature}

Our paper mainly contributes to the literature on social and political determinants of urban planning decisions and the use of event studies, or quasi-natural experiments, to tease out potential causal relationships in terms of political favouritism at sub-national levels of government (Lubell et al. , 2005; De Figueiredo \& Richter, 2013, Calabrese et al. , 2007, Solé-Ollé \& ViladecansMarsal, 2012, Dehring et al. , 2008; Hilber \& Robert-Nicoud, 2013; Engle et al. , 1992; Solé-Ollé \& Viladecans-Marsal, 2013; Schone et al. | 2013). Additionally, the paper is a demonstration of how relationship networks, in addition to direct political connections, can enable valuable favour exchanges in local and State level politics in a relatively low corruption country. We briefly review the papers closest to ours.

Solé-Ollé \& Viladecans-Marsal (2012) look at political determinants of the ratio of new land assigned for urban development within Spanish municipalities, using a data sample of 2,034

\footnotetext{
${ }^{2}$ For example former Brisbane Mayor and Queensland Premier Campbell Newman's close school friends and father-in-law are property developers (Callinan 2012).
} 
municipalities over the period 2003-07, which covers a single municipal political term. They ascertain that electoral margins are significantly related to the decision of how much land is rezoned for development, with tighter margins resulting in less rezoning. In later work, Solé-Ollé \& Viladecans-Marsal (2013) use this data to look at the influence of political parties on urban zoning using a regression discontinuity design that looks at party incumbency while controlling for the vote share, finding that left-wing governments rezoned $65 \%$ less than similar right-wing governments in their preferred model specification. These two studies primarily concern the decision to rezone in the first place. Where we differ from these studies is that our primary interest is the secondary decision of the precise locations of newly rezoned areas, which is where the winners and losers are ultimately determined and where relationships and organised interests perhaps play a greater role. We hypothesis that for the 'growth coalition' it is not so important where the precise boundaries are, but such knowledge is crucial for the individual property developer who has taken up an asset position prior to rezoning.

In a study of the role of these competing interests in urban planning decisions, Schone et al. || (2013) look at the taxe locale d'équipement (TLE), a local development tax similar to North American impact fees in the 293 municipalities in the French Rhône Department. TLE is paid to the municipality by developers when they are granted a building permit and is levied at a politically determined rate of the estimated building value (which can be up to 5\%). By examining variables capturing lobbies of aligned interest: $3^{3}$ and controlling for interactions with neighbouring municipalities, they find that a larger homeowner lobby is related to a higher TLE rate, while a larger undeveloped landowner lobby is related to lower TLE rate, indicating that urban planning policies can be swayed by their direct beneficiaries. They found no effect on TLE rates from the size of the construction sector, indicating that the 'growth machine' alliance differs due to local circumstances: a lower TLE rate is beneficial only for owners of undeveloped land and may not affect the rate of new construction. Like our study, Schone et al. (2013) cleanly identify the winners and losers of an urban planning decision, and look closely at the relative dominance of vested interests in planning outcomes. Where we add to these results is that we more directly measure both ownership of actual properties and the network characteristics of owners.

In terms of quantifying the payoffs from direct political connections to local government, Amore \& Bennedsen (2013) use an event study of changes to municipal boundaries in relatively uncorrupt Denmark where the number of politicians-per-person exogenously decreased in some municipalities but not others, which the authors interpreted as an increase of the political power of the population in municipalities. They test whether this increase in political power had an effect on the profitability of firms with family ties ${ }^{4}$ to those politicians, finding an increase in operating return on assets for family-connected firms of 3.3\%, reflecting an elasticity of firm performance to political power of family members approximating unity. This strong effect of family ties in a low-corruption country suggests that local level corruption in property zoning allocations is easier to sustain and harder to eradicate than corruption at the more visible national level. Our study too deals with relationships at a sub-national governments level, though we more directly observe the full set of winners and losers, as well as non-family relationships with others in the property market networks.

This clear evidence of payoffs from direct reciprocity between family members is broadly in line

\footnotetext{
${ }^{3}$ Their variables are somewhat indirect since some the key variables are unobserved: they hence proxy ownership of existing developed land in a municipality by the home ownership rate; ownership of undeveloped land is proxied by the proportion of farmers in the population; and the 'growth machine' lobby is proxied by the share of employees in the construction sector.

${ }^{4}$ Parent, child, sibling and current or former spouse(s).
} 
with many other findings of the payoffs to direct political relationships in other countries such as Italy (Cingano \& Pinotti, 2013), China (You \& Du, 2012) and Indonesia (Fisman, 2001), amongst others ${ }^{5}$ (Hillman, 2005; Faccio, 2006, Faccio et al. , 2006, Chen et al. , 2011).

At a more general level, these studies fit into a growing literature demonstrating the role of relationship networks in sustaining implicit favourable exchanges at the political level (Fischer, 2013: Dassen, 2010; Howlett, 2002; Jackson et al. , 2012). Typically an advantageous position in a relationship network is described by the term 'social capital'. Yet, exactly which characteristics of the relationship network provide value remains contested (Burt, 2000, Durlauf, 2002, Svendsen \& Svendsen, 2009, Chai \& Rhee, 2010). Coleman's (1990) view is that value arises from closure within a network, that is, the local density of relationships provide the mechanism for small groups to monitor and pressure each other to behave in a particular cooperative way. In contrast, Burt (1995) suggests that brokerage across structural holes, connecting otherwise disconnected parts of the network, provides a positional monopoly that has value for an individual as they are the sole broker across different parts of the network ${ }^{6}$ By looking at multiple relationship network metrics we are able to provide some evidence on which underlying network characteristic appears dominant in terms of payoffs from rezoning decisions in Queensland: having close ties in a sub-group ('closeness') or being the common element across many sub-groups ('betweenness'). These indirect network characteristics are particularly important because direct relationships between land owners and politicians arouse suspicion, and have the potential to lead to corruption complaints and prosecution (CMC, 2009) 7

In sum, the main contribution of this paper is to look at the micro-mechanism of influence by vested interests in rezoning decisions, thus complementing previous work showing that indeed urban planning outcomes at municipal levels reflect local interests. As the mechanisms for influence we examine relates to the position of land owners in a relationship network, our study also provides evidence to discern between two major competing theories of network influence.

\section{$3 \quad$ Institutions}

\subsection{Timeline and planning processes}

In Queensland, property owners and property developers who want to change the use of their land have to go through an approval process with their local council. Approvals can be sought for increasing the building-density (floor area ratio), and/or building-type, to the maximum allowed for the zoning type the land falls within. Both the decision to approve land use changes within a zone, and the decision of what the zone and its associate development limits will be in an area, is mainly a matter for local councils, of which there are 77 in Queensland. Our focus is on the period 2004-12 in which the State took both these planning responsibilities away from local councils in a number of areas.

Following the early 2000s house price boom, the Queensland government implemented two parallel planing processes: first, in 2004, it published an overall plan establishing an intention to

\footnotetext{
${ }^{5}$ Though in contrast, Gray et al. (2014) found that in Australia during the 2004-2011 period the appointment of a politically connected directors had no substantial direct impact on shareholder value for listed companies.

${ }^{6}$ This is a reformulated and extended view of the 'strength of weak ties' argument (Granovetter 1985 2005).

${ }^{7}$ Many direct relationships that exist in reality are likely to be concealed from the public records used to assemble our dataset. This is likely to bias results against an importance of centrality, since the single valuable bridging relationship, such as a family member with connections to both politicians and property owners, is the very type of relationship likely to be concealed from public records.
} 


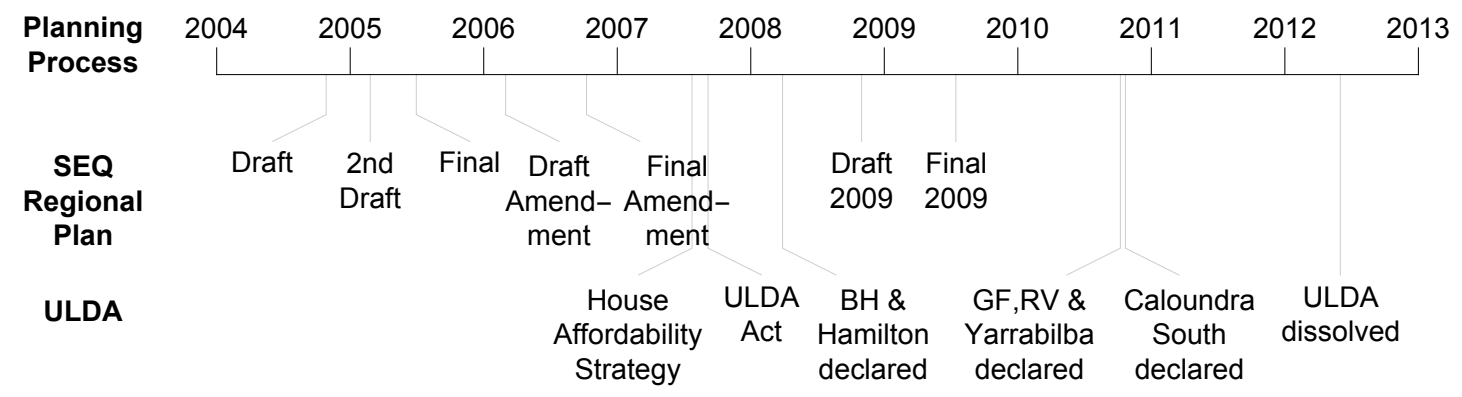

Figure 1: Timeline of Queensland's parallel planning processes

rezone, as well as an initial map of the relevant potential rezoning areas; second, it took planning powers away from local councils in designated areas by way of the Urban Land Development Authority (ULDA), set up in 2007 and in operation until 2012, during which the ULDA decided on 17 new rezoning areas. A decision by the ULDA on a rezoned area thus reset the area's zoning-type and simultaneously designated the rezoned areas as falling under the approval process of the ULDA, not the councils. A timeline of these two distinct and conflicting planning processes, including the various drafts and amendments, is provided in Figure 1 .

The first of these planning processes was the South East Queensland (SEQ) Regional Plan 20052026, the purpose of which was to

...guide growth and development in SEQ to 2026. It also identifies areas that, subject to further investigation, may be suitable for medium to longer-term development. The extent to which this urban pattern is achieved will depend upon a number of factors, including future growth rates, community attitudes and behaviours, government regulation, the ability to provide infrastructure efficiently and technology (Mackenroth, 2004).

This State-level plan occupied the top of the planning hierarchy, meaning that local councils were to ensure their planning schemes were consistent with this overarching plan. Thus through this process the State indirectly controlled planning outcomes, but local councils still determined their own zoning areas and approved new developments. The plan itself evolved through time, with multiple drafts and amendments reflecting results of various consultation efforts, and an updated plan was finalised in 2009.

Alongside this supposedly technical planning process, the State government announced on 25 July 2007 a Housing Affordability Strategy which flagged the creation of a statutory body, the ULDA, via the Urban Land Development Authority Act 200\%, which was passed just 6 weeks later on 6 September 2007. The stated intention was:

For sites nominated by the Queensland government, the role of the Authority will be to undertake land use planning, land amalgamation and acquisition, land improvement, development assessment and then on-sell land and development rights to private sector developers (DIP, 2007).

Nine areas were flagged for inclusion: Woolloongabba, Bowen Hills, Northshore Hamilton, Fitzgibbon, Mackay showgrounds, Yarrabilba, Caloundra South, Coomera, and Ripley Valley. Of these areas, Woolloongabba, Fitzgibbon and Mackay showgrounds were fully State-owned or controlled sites, and Coomera never came under ULDA control. Of the 5 areas later declared 
under the control of the ULDA four these, with the exception of Greater Flagstone, were also State-controlled sites. In the remaining areas, most land was privately owned, meaning that all benefits from the increased development densities that accompanied ULDA declaration would accrue to private land owners. It is thus these six areas that we focus on, since the determination of these exact rezoning areas may reveal the political influence of land owners in and around these areas. The exact rezoned areas were declared between 2008 and 2010: Bowen Hills (BH) and Hamilton Northshore (HN) - 28 March 2008, Greater Flagstone (GF), Ripley Valley (RV) and Yarrabilba - 8 October 2010, and Caloundra South - 22 October 2010. By law the ULDA was to take advice from the relevant Minister when considering the declaration of areas to fall within its planning power, providing an avenue for political influence.

Figure A.1 in the Appendix shows the evolution of the intended rezoning areas as identified in the SEQRP process, as well as the final ULDA areas. What is striking is how different the actual decisions are from the previously stated intentions: in all cases, the final decision is in another place and comprises a much smaller area than in the original SEQ Regional Plan, or even of the updated SEQ Regional Plans. For instance, for Greater Flagstone and Yarrabilba, the final rezoning in 2010 is in a completely different place to the intended rezoning area of 2009. For the Ripley valley and Caloundra South, the eventual zone is a small subset of the intended zone announced as late as 2009.

Since the councils were supposed to be preparing for the future based on the SEQRP plans, we consider the local Council planning process underway for each eventual ULDA area in turn, providing prima facie evidence of whether the councils were responsible for the eventual rezoned areas or whether other interests drove it.

First, the Ripley Valley area falls within the borders of the Ipswich City Council, which flagged this area for future development in their Ipswich Consolidated Planning Scheme, implemented in December 2005, which fed into the draft of the first SEQ Regional Plan. The eventual outcome was a subset of the area that the council had in mind, and had little to do with the area that the SEQRP had designated as an area worth investigating.

The Caloundra South area fell within the borders of the Caloundra Council prior to its amalgamation into the Sunshine Coast Regional Council in 2008. The eventual ULDA area at Caloundra South was first promoted as a location for urban development in 1988 by the Emanuel Group corporation, but even up till 2004, the Caloundra City Plan designated the area no more than a 'Further Investigation Area' with no firm plans for rezoning, essentially because of environmental protection concerns (the area was covered by flooding and wetlands protection legislation). Yet, in 2004, Stockland, a stock-exchange listed Queensland developer, acquired Lensworth Ltd, a Fosters Group company that had owned the site since 1998. In that same year, the site suddenly became a feature of State-level planning documents, including the first Draft SEQRP. When the site was declared by the ULDA, the local media reported that then State Premier Anna Bligh acknowledged she had received representations from the developer prior to taking the step of declaring the area under the control of the ULDA.

Yarrabilba and Greater Flagstone fell within the jurisdiction of Logan City Council. Prior to the ULDA declaration in October 2010, Logan City Council had adopted its own Yarrabilba Land Use Structure Plan (LUSP) in March 2010 that complied with the SEQ Regional Plan and that in large part was consistent with its own 2004 plan. Yet, the eventual ULDA decision bore no resemblance to either the 2004 plan, or the March 2010 plan.

Importantly, at the time of the ULDA declaration, Yarrabilba contained a large tract of land held under option since 2003 by the Lend Lease company, which had already lodged a development 
application to override the Council planning scheme (zoning). A screenshot of internal Lend Lease documents in Figure A.2 of the Appendix details the long and complicated process that Lend Lease had gone through, unsuccessfully, to get approval from the Logan council. Where the company failed with the council, it succeeded with the ULDA, to the apparent surprise of the council.

The case of Yarrabilba shows a direct and successful attempt of a property developer getting the State to do its bidding, in the form of a 'grabbing hand' series of planning decisions by the State. Even as of 2015, there is likely to be continued influence by Lend Lease on the planning process, as their internal reports suggest a strategic goal to develop the whole area for urban development, even though most of the site remains outside of the urban footprint designated in the current SEQ Regional Plan.

The Greater Flagstone ULDA area included a relatively small area determined as suitable for urban development by the Logan City Council in 2009 following a 'structure planning process', and reflecting the March 2006 SEQ Regional Plan Amendment. The eventual ULDA area only contained previously announced areas in about $20 \%$ of the ULDA area, with $80 \%$ being outside of announced prior plans. Importantly, one large corporation owned the $20 \%$ : the MTAA Superannuation fund, which purchased 1,244Ha of land in March 2000, the majority of which falls within the ULDA boundary. That corporation had in fact already started construction prior to the ULDA announcement and was a recognised lobbyist and donor.

The timelines, land purchases, and evidence of direct lobbying, show the political importance of a few major and visible developers at the State level for three of the six ULDA areas. Whether this pattern systematically holds for less influential land owners and developers is crucial to understanding the complete picture of political influence in rezoning.

\subsection{History of corruption in Queensland}

The Queensland State government has a well-documented history of corruption, particularly in regards to property markets (Jackson \& Smith, 1995, Williams, 1999, Dodson et al. , 2006) 8 8 The biggest effort to make Queensland politics more accountable followed a high-profile inquiry led by former judge Tony Fitzgerald, whose 1989 report prompted the establishment of anti-corruption institutions and lead to the imprisonment of several politicians.

However, Tony Fitzgerald had this to say twenty years later in 2009 about the state of corruption in Queensland: "Access to government can now be purchased, patronage is dispensed, mates and supporters are appointed and retired politicians exploit their political connections to obtain success fees for deals between business and government" (McCutcheon, 2009). Similarly, Dodson et al. (2006) provides a coherent summary of the extensive criminal investigations into misconduct surrounding building and planning permissions in Australia, and a selection of cases where criminal misconduct was found to occur. They note that

[t]here is barely a week that passes without a media report somewhere in Australia alluding to an improper governance or procedural action in the land development. Queensland is particularly renowned as a place where corrupt land development practices were allegedly allowed to flourish for decades... (Dodson et al. ,2006).

\footnotetext{
${ }^{8}$ One potential reason for this is the lack of democratic control: Queensland only has one house of parliament, with the ruling party being in near total control of the state. Queensland has also seen long periods of one-party rule: 32 years by the Nationals from 1957 to 1989, and then 22 years by the Labour government till 2012.
} 
A typical example of the close connections between politics and property in recent times is given by Campbell Newman, State Premier from 2012 to 2015, who failed to declare his wife Lisa Newman's stake in a property that won high rise development approval from Brisbane City Council at the time that he was Lord Mayor of Brisbane, providing his wife windfall gains of millions of dollars (Wardill \& Helbig, 2011). In Queensland such connections are not strictly illegal, and there were no adverse consequences to Newman from this incident.

Similarly, the former Minister for Planning and Infrastructure, Terry Mackenroth, was investigated by the Crime and Misconduct Commission (CMC) following allegations he had "improperly influenced a review process by which certain land came to be included in the urban footprint contained in the 2009 SEQ plan" (CMC, 2009). Upon retirement he became a board member of Metro, a local property development company run by industry heavyweight David Devine. He was later criticised in the media for abusing his personal connections to gain development approvals for Metro beyond the scope of zoning limits (Hele \& Stolz, 2006).

Other evidence of the importance of connections in the property markets in Australia comes from a recent inquiry by the New South Wales Independent Commission Against Corruption (ICAC), Operation Spicer, that lead to the resignation of over a dozen politicians. This inquiry exposed the repeated circumvention of political donations laws prohibiting property developer donations. Such laws restricting developer donations have never existed in Queensland, and were only introduced in the state of NSW by amendments to the NSW Election Funding, Expenditure and Disclosure Act 1981 in 2009 due to the ongoing suspicion that rezoning decisions were being bought through political donations.

Additionally, 44 of Queensland's top 100 wealthiest families made their money in the property and construction industry ${ }^{9}$ From an economic perspective this should be surprising since these industries appear competitive, with low barriers to entry and stable technologies. However, their reliance on discretionary government decisions in the form of land zoning, development approvals, and tendering construction contracts, makes them prime candidates for political rentseeking. Relatedly, property developers and construction companies dominate the registers of political donors in Queensland and elsewhere in Australia.

\subsection{The other ULDA re-zoned areas}

One might think that our selection of privately owned ULDA areas implies the absence of political rent-seeking problems in the other areas that were exclusively State-owned. This, however, is not necessarily true.

Take the example of the area of Fitzgibbon. Robertson (2011) notes that

Land is not available to be purchased by individuals, only to preferred developers and builders. These preferred developers and builders then on-sell land to purchasers. The developers are selected through an open tender process "to become partner builders."

Hence, again, the political process created clear discretion to select the politically connected preferred developers on favourable terms. There is thus little a priori reason to expect the political favouritism in land development for these State-owned areas to be qualitatively different than for the privately-owned areas. It is only because we are unable to know which builders and

\footnotetext{
${ }^{9}$ Based on News Corp Australia's Richest 100 List (The Sunday Mail 2008).
} 
developers lost out in this selection process, that we focus on the ULDA areas where the majority of the land was privately owned prior to rezoning.

\subsection{Identification}

In general, a correlation between land owner relationships and rezoning success does not imply causation. The main alternative hypothesis is that well-connected land owners may simply possess expertise that allows them to better predict which areas will be suitable for urban expansion.

Our land owner sampling method controls for this possible causal relationship by ensuring our control group of non-rezoned land owners possess close to identical locational and land size characteristics. We discuss in detail the sample selection criteria in Section 4.1.1 but here note that our procedure of selecting the 'losers' from rezoning as landowners immediately outside the ULDA boundaries, controls for land size and location relative to natural boundaries such as rivers, rail lines and highways. This method is illustrated by examining the Greater Flagstone and Yarrabilba ULDA areas shown in Figure A.1 of the Appendix. In the early versions of the SEQRP a large Beaudesert Investigation Area encompassed both of the eventual two rezoned areas. Our sample of land owners just outside the ULDA areas are contained within the investigation areas, and as such, control for locational characteristics and the previously best public information about future rezoning intentions.

Informal interviews with public servants, developers and former politicians also point to a widely held view within the industry that selectively rezoning land owned by developers is better at promoting development than rezoning land 'owned by grandmas'. Not only does this suggest that indeed there is favouritism occurring, but even if this rationale had merit on efficiency grounds there would be no justification on welfare grounds to refrain from pricing the value gains from rezoning rather than giving them to particular land owners for free, and not giving such favours to unconnected land owners.

\section{Data and Methods}

We assemble two types of data: core data on land, land prices, and rezoning status over time; and a database of all elements we can measure that will co-determine the political connectivity of a large set of individuals and entities (corporations, politicians, bureaucrats, landowners). We then use network techniques to extract measures of political connectivity of the landowners in our core database, which is subsequently used for our main analysis on who gets the political favours and how much those favours are worth.

\subsection{Data}

\subsubsection{Land}

Land records for the sample come from the database of Queensland land titles reseller, RPdata.com. We use a custom map logging tool to capture land ownership and sales details of land lots that fell inside and immediately outside each of the six ULDA areas of interest. The outside control group includes sites between the zoning boundary and the next 'natural' boundary, which we consider to include major watercourses, highways and railways. Ownership of land parcels 
that had been developed between the ULDA declaration date and the time of the data gathering was tracked back through titles searches from the Department of Environment and Resource Management (DERM), and company records where available.

From this initial data, land parcels outside ULDA boundaries were excluded if they were owned by a public entity, already developed, or if the lot size was smaller than the smallest lot inside that ULDA area. This filtering ensured that outside lots remaining in our sample were comparable in terms of location, size and level of development, with the inside rezoned lots. This procedure resulted in a sample of 1,192 land parcels, 274 of which were inside ULDA boundaries. These 1,192 parcels had 1,137 different registered owning entities. Details of the land and owner sample are in Section 5.2 and an example of the sample of landowners is shown in Figure 210



Figure 2: Land locations (blue/red disks are inside/outside lots, sized to lot area)

For each lot, we record historical sales dates and prices in order to test for differences in price paths generated by the ULDA declaration, enabling us to estimate the likely size of the rent allocation towards the rezoned landowners.

\footnotetext{
${ }^{10}$ Clockwise from top left: Ripley Valley, Northshore Hamilton, Yarrabilba, and Greater Flagstone.
} 


\subsubsection{Political donors}

Two data sources were used to generate a list of political donors that was then merged with the landowner data: the Electoral Commission Queensland (ECQ) records of political party fundings, which covers all transactions from party accounts above $\$ 1,000$, and the Australian Electoral Commission (AEC) records of all donations above $\$ 10,000$ Records from the ECQ for the period 2007-2012 were manually transcribed into a database from ECQ archives, including donations that were being funnelled through associated entities, such as Labor Holdings Pty Ltd and Forward Brisbane Leadership, providing a list of 1,537 donors and the amount donated, of which 613 were donors to the Labor party which held power during this time.

\subsubsection{Lobbyist clients}

Since 2010, following the passing of the Integrity Act 2009, the Queensland Integrity Commissioner has maintained a register of Queensland lobbyists, their staff and clients, both current and historical. The full register was included in our database in July 2012. These records cover entities that carry out lobbying activity to a third party for "a fee or other reward", which means it very narrowly covers some professional lobbyists, many of whom are former politicians or senior government employees. It does not include industry groups or professional bodies whose main role is to lobby government in the interest of its members. Since the records match clients to lobbyists, these records provide a landowner characteristic variable to the data in the form of whether the landowner is a client of a professional lobbyist, and also provides a link from client to lobbyist in the construction of a relationship network.

\subsubsection{Industry associations}

The Property Council of Australia (PCA) and the Urban Development Institute of Australia (UDIA) are the two major property development industry groups in Queensland. The existence of such professional groups provides another potential avenue to generate corporate and political connections. Online records of individual and corporate members of these respective groups where compiled in March 2012, with additional records for the PCA obtained from 31 July 2008 via the WayBack Machine internet archive. This produced 1,065 individual and corporate entities associated with the PCA, and 253 entities associated with the UDIA, with 1,283 unique entities altogether. The data are used to both generate UDIA and PCA industry group dummy variables for land owners, but also to create a core network of relationships between members; that is, all members of each industry group in our network are connected to all other members.

\subsubsection{Politicians}

Queensland Parliament publishes a Re-Member Database of biographical information on current and former members of Parliament. We use this database to generate a list of elected parliamentarians from 1998 to 2012. These names were included in the relationship network, connected to other entities through lobbying activities, industry groups membership, or corporate connections. Because family member names were only sporadically available in this database, such relationships are not used in this paper.

\footnotetext{
${ }^{11}$ The threshold for declaration was set at $\$ 10,000$ in 2005 and has incrementally been increased to $\$ 12,800$.
} 


\subsubsection{ULDA staff}

All ULDA staff and board member names were sourced from published annual reports till 2012 and included in the data set, with network connections to their published previous employers.

\subsubsection{Corporate relations}

For the 174 corporate land owners in the sample, records from the Australian Security and Investment Commission (ASIC) of current and historical office holders, senior staff and related entities were compiled. This data generated network links between corporate land owning entities, their directors and principle owners in the combined data set. In all 1,795 entities were linked by the resulting networks of corporate connections.

Data were cleaned and matched. Following basic automated name matching, manual matching was undertaken to unify the data using web-search checks to identify companies and institutions that had new and old names recorded from different data records, and to merge individuals where they sometimes recorded common nicknames.

Matching our data created a network of 13,740 entities with 272,810 edges, consisting of all entities, individual and corporate, from all the above mentioned datasets combined. Edges in the network arise from corporate connections, industry connections, lobbyist connections and former employers of lobbyists, and the corporate and internal connections of the ULDA board of directors and senior staff.

\subsection{Methods}

\subsubsection{Rezoning success model}

Our main outcome of interest is whether landowner $i$ gets a favourable rezoning decision or not, depending on landowner characteristics, using the following linear probability model

$$
I_{i}=X_{i}^{\prime} \beta+\operatorname{Pol}_{i} \gamma+e_{i}
$$

where $I_{i}$ is the share of land of each landowner $i$ that fell within the rezoned area; $X_{i}$ is a matrix of characteristics of the land in the sample; $P$ olC $C_{i}$ is a measure of the political connectivity of each landowner, implying that $\gamma$ denotes the increase in the chances of getting favourable land rezoning due to political connections; and $e_{i}$ is the error term. PolC $i$ includes whether or not a landowner uses a lobbyist, makes donations, is well-connected in the relationship network and so on. The construction of the variables in it are revisited later.

\subsubsection{Price model}

To identify the price effects of the rezoning decisions, which enables an estimate of the size of the economic rents allocated to rezoned land owners, we model lot prices using historical sales records, and include a number of control variables, such as lot size, a Brisbane house price index, and ULDA area dummies in the form 


$$
\ln \left(P_{i t}\right)=X_{i}^{\prime} \alpha+a W_{i t}+b L_{i t}+e_{i}
$$

where $\ln \left(P_{i t}\right)$ is the logarithm of the sale price per hectare of lot $i$ and time $t, X_{i}$ is a vector of control variables for each lot, $W_{i t}$ is dummy variable for lots $i$ at time $t$ that fall within ULDA areas after the time of their declaration, and $L_{i t}$ is the dummy variable for lots outside the ULDA declared area but that could have been inside in terms of proximity and land characteristics. In this linear probability model, the price variable is a log price per area, meaning that the estimated coefficients can be used to discern the price impact of the ULDA decision to rezone in the form $\left(e^{\hat{a}}-e^{\hat{b}}\right)$. This relationship is also tested with a number of leads and lags around the declaration date in order to better understand the price path: if rezoned land owners posses political privilege then it could be expected that other speculators move in to the area in anticipation of favourable decisions, bidding up land prices prior to the actual declaration.

Using the estimated parameter coefficients from Equation 2, along with a vector of land sizes, $A_{i}$, we can for each plot of land calculate the expected price as

$$
\begin{aligned}
E\left[P \mid X_{i}^{\prime}\right] & =\int\left[\operatorname{Pr}\{W=1, L=0\} e^{X \widehat{\alpha}+a+e_{i}}+\operatorname{Pr}\{W=0, L=1\} e^{X \widehat{\alpha}+b+e_{i}}\right] d G\left(e_{i}\right) \\
& =e^{X \widehat{\alpha}+\hat{\sigma}^{2} / 2} \times\left[e^{\hat{a}} \operatorname{Pr}\{W=1, L=0\}+e^{\hat{b}} \operatorname{Pr}\{W=0, L=1\}\right]
\end{aligned}
$$

where $G\left(e_{i}\right)$ is the distribution of $e_{i}, \widehat{\alpha}$ is the vector of coefficients estimated from Equation 2, $\hat{a}$ and $\hat{b}$ are now the coefficient estimates from Equation 2 and $\operatorname{Pr}\{W=1, L=0\}$ denotes the probability of successful rezoning. If we first look at potential rents available had all lots in our sample been rezoned, $R$, we can calculate this as the expectation of the price-difference inside and outside the rezoned areas for all lots using the point-estimates of the coefficients, and taking the expectation over the error term in Equation 2 as

$$
R=\sum_{i} e^{X \widehat{\alpha}+\hat{\sigma}^{2} / 2} \times\left(e^{\hat{a}}-e^{\hat{b}}\right) \times A_{i}
$$

where $X$ now is used to denote the matrix of the control variables used in Equation 2 for our sample of landowners, and $A_{i}$ is the area of land for each $i$ landowner in the sample.

To calculate the size of the actual rent allocation in our sample from the rezoning boundary decisions, we can premultiply $A_{i}$ by a vector of land-shares falling inside the rezoned areas for each owner, $I_{i}$. Of those actual gains we can estimate the share that went to rent-seekers by premultiplying $A_{i} \times I_{i}$ by a vector of $\{0,1\}$ dummies that denote our classification of being a rent-seeker in terms of being connected or undertaking any lobbying and donation activity.

In terms of the marginal gains to political connectivity for all landowners, $R_{c}$, we premultiply $R$ by $P o l C_{i} \hat{\gamma}$, which is a direct measure of the gains to successful rezoning by political connections in these areas, i.e. it is

$$
\begin{aligned}
R_{c} & =E \sum_{i} A_{i}\left(P\left[\text { Pol }_{i}\right]-P\left[\text { Pol }_{i}=0\right]\right) \\
& =\sum_{i} e^{X_{i} \widehat{\alpha}+\hat{\sigma}^{2} / 2} \times\left(e^{\hat{a}}-e^{\hat{b}}\right) \times A_{i} \times \text { Pol }_{i} \hat{\gamma}
\end{aligned}
$$


where the only difference between $P\left[\mathrm{PolC}_{i}\right]$ and $P\left[\mathrm{PolC}_{i}=0\right]$ is due to the higher probability of getting favourable rezoning.

\subsubsection{Network measures}

There are a large number of ways in which we can use our network data to generate landowner specific measures of connectivity. Since we have little ex ante theory to guide our choice of measure, we adopt the measures used by previous scholars that arguable match the competing conceptions of social capital.
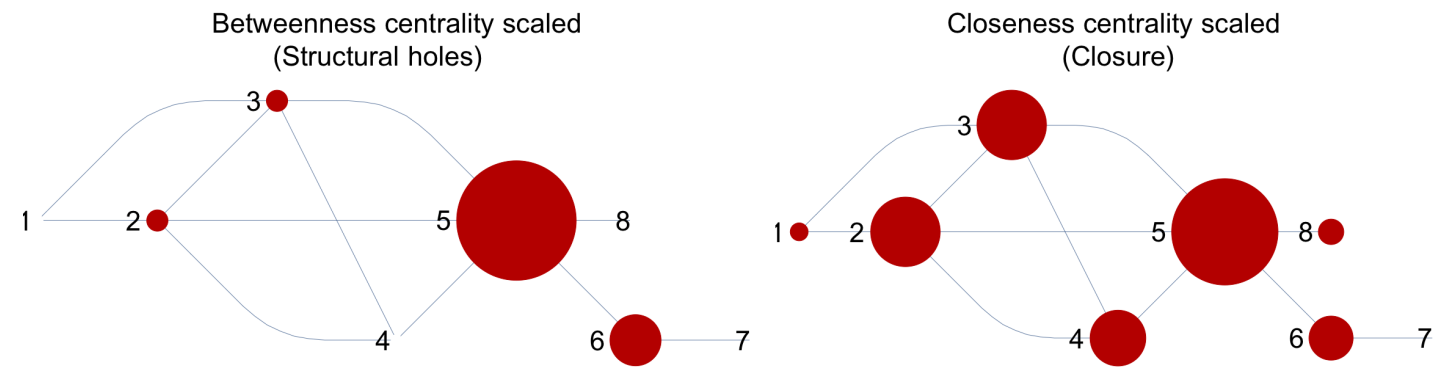

Figure 3: Conceptual diagram of network neasures

Our closeness centrality (or closure) measure of land owners in the relationship network is derived from the mean length of all shortest paths from them to every other node connected in the network, providing an measure between 0 (completely disconnected) and 1 (directly connected to every node in the network) ${ }^{12}$ In previous studies, this measure has been shown to predict evaluated individual job performance, and is argued to be the primary measure of mutual supervision and ability to coordinate (Brass et al., 1998 , Sparrowe et al. , 2001).

To proxy for Burt's (2000) view of social capital as bridging structural holes, we also include a measure of betweenness centrality 13 , which is a measure of the centrality of a node in a network based on the number of shortest paths that pass through it, indicating a positional monopoly on information flow through the network.

To clarify the intuition behind these two measures we use the example network in Figure 3 with node (or vertex) size scaled by each centrality measure. Notice that in terms of betweenness centrality, node 5 has by far the largest measure. This is because all paths between nodes 6,7 or 8 , and nodes $1,2,3$ or 4 must pass through it, meaning that for any information to flow from the nodes on the left to those on the right relies on node 5 having access to that information. This monopoly on the information flow provides the underlying logic of taking the "bridging of structural holes' as a measure of connectedness.

Closeness centrality on the other hand represents, in economic terms, having a large closely connected network which can sustain and reinforce norms of behaviour due to intensive monitoring ability (everybody is well connected enough to observe most other's behaviour). Node 4 has a

\footnotetext{
${ }^{12}$ Closeness centrality for vertex $i$ in a graph is given by $\frac{1}{l_{i}}$ where $l_{i}$ is the average distance from vertex $i$ to all other vertices connected to $i$.

${ }^{13}$ Betweenness centrality for a vertex $i$ in a connected graph is given by $\sum_{s, t \in v \wedge s \neq i \wedge t \neq i} \frac{n_{s, t}^{i}}{n_{s, t}}$ where $n_{s, t}$ is the number of shortest paths from $s$ to $t$ and $n_{s, t}^{i}$ is the number of shortest paths from $s$ to $t$ passing through $i$.
} 
well connected clique ${ }^{14}$ involving nodes $2,3,4$ and 5 . Hence, while node 4 has no monopoly in information flow (a zero betweenness centrality because of the shorter substitute paths through their clique from nodes 1 to 6,7 and 8 ), it forms a critical element of the formation and enforcement of norms within its clique and thus has a high closeness centrality measure. These two network measures hence capture different elements of coordinating behaviour that may comprise social capital.

\section{Results}

\subsection{Political connectivity}

We first analyse the relationship network data in order to look at political connectivity. The main component in our network is made up of the largest set of connected nodes, which in our network contains 6,729 entities which are either individuals or companies. The next largest connected component in the network comprises just 44 entities and hence is only of marginal relative interest.

Only one politician is in the main component while 56 landowners are. This is surprising, given the widespread media focus on the revolving-door between politics and property developers. One reason for this is the difficulty of tracing suspicious relationships. For instance, we know from the corporate website at the time that the former Minister for Planning Terry Mackenroth was on the Board of Directors for Metro Properties, a land owner in our sample. Yet, because we cannot observe such connections with the same degree of certainty for all the politicians and others in our network sample (simply because the data is unavailable and subject to privacy legislation), we cannot use this type of information. We thus have to rely on the assumption that what is important about the observed relations (betweenness or closeness) is also what matters for the unobserved relationships.

Table 1: Network clustering characteristics

\begin{tabular}{rrrrrrrrrr}
\hline \hline Cluster & Nodes & Edges & $\begin{array}{r}\text { Average } \\
\text { close. } \\
\text { cent. }\end{array}$ & $\begin{array}{r}\text { Average } \\
\text { between. } \\
\text { cent }\end{array}$ & $\begin{array}{r}\text { Land owner } \\
\text { node share }\end{array}$ & $\begin{array}{r}\text { Lobbyist } \\
\text { client } \\
\text { node share }\end{array}$ & $\begin{array}{r}\text { Industry } \\
\text { node share }\end{array}$ & $\begin{array}{r}\text { Corp. } \\
\text { edge } \\
\text { share }\end{array}$ & $\begin{array}{r}\text { ULDA } \\
\text { staff } \\
\text { edges }\end{array}$ \\
\hline & 4,016 & 12,953 & 0.22 & 1.1 & 0.0230 & 0.77 & 0.01 & 0.07 & 1 \\
- & 653 & 170,770 & 0.32 & 3.3 & 0.0026 & 0.25 & 0.62 & 0.01 & 6 \\
- & 463 & 62,894 & 0.25 & 0.32 & 0.0088 & 0.02 & 0.81 & 0.12 & 105 \\
0 & 426 & 447 & 0.21 & 0.80 & 0 & 0.95 & 0 & 0 & 0 \\
- & 279 & 25,526 & 0.27 & 0.44 & 0.0018 & 0.16 & 0.64 & 0.20 & 0 \\
\hline \hline
\end{tabular}

Betweenness centrality rescaled by $1 / 10000$

The main component in the network can be subdivided in 5 main cluster ${ }^{15}$ shown in Figure 4 and also in Table 1. The figure shows the rather high degree of connectedness of the main component, with 268,233 edges. The red cluster contains 4,016 entities, of which 26 are land

\footnotetext{
${ }^{14} \mathrm{~A}$ grouping of nodes with all possible edge combinations.

${ }^{15}$ Modularity clustering algorithm used based on Newman (2006) and implemented in Mathematica 10.0.1
} 

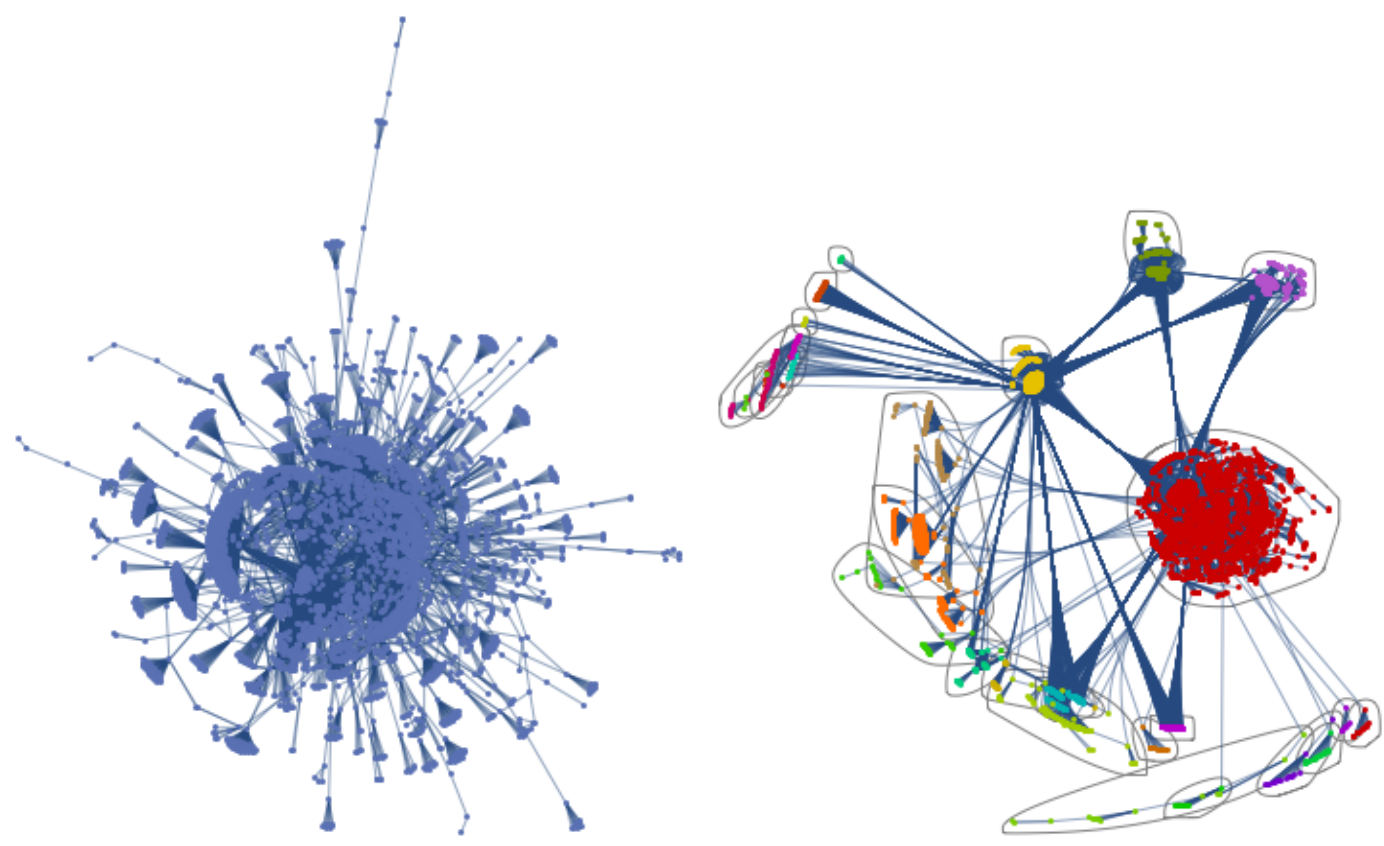

Figure 4: Relationship network main component

owners, and the majority of connections arise from connections through professional lobbying activity. The central yellow cluster comprises 653 entities with the majority of edges formed by industry groups connections. The third largest cluster is the top right purple cluster consisting of 463 entities connected by a mix of lobbyist, industry and corporate edges, and many of the ULDA board members and senior staff.

As Table 1 further shows, the clusters largely reflect the data sources used to generate the network: the third cluster is largely from PCA membership and the fifth cluster largely from UDIA membership. We do find though that employing a lobbyist and being a member of an industry group seem substitutes, with very rare cases of overlap. The second and third largest clusters (yellow and purple) display the closeness one needs for mutual monitoring: these clusters have relatively few nodes (653 and 463), yet an exceptionally high number of relationship edges $(170,770$ and 62,894$)$ in comparison to other clusters in the main component. If members of these clusters are hence particularly often successful in terms of favourable rezoning decisions, then that would show up in our analyses as a high importance of closeness centrality.

\subsection{Summary data on ULDA areas}

Tables 2 and 3 give the key statistics on the land sample inside and outside of the ULDA rezoning decisions. A key point in the construction of the outside area was to ensure all lots are at least as large as the smallest lots from the sample inside the ULDA area. For the Caloundra South area it turned out that no adjoining lots are at least the size of the three lots within the ULDA area, which means the Caloundra area only has an internal area treated on a par with the other five internal areas. The main point of the Tables 2 and 3 are that the inside lots are usually larger than the outside lots, meaning that lot size is an important variable to account for in regressions. 
Table 2: Land lot sample summary

\begin{tabular}{|c|c|c|c|c|c|c|c|}
\hline \multirow[t]{2}{*}{ ULDA area } & & \multicolumn{5}{|c|}{ Lot Area Details (Ha) } & \multirow[t]{2}{*}{ Total lots } \\
\hline & & Mean & Median & Maximum & Minimum & Total & \\
\hline \multirow[t]{3}{*}{ Bowen Hills } & Whole & 0.11 & 0.05 & 3.3 & 0.03 & 20.9 & 191 \\
\hline & Inside & 0.12 & 0.06 & 3.3 & 0.03 & 14.4 & 124 \\
\hline & Outside & 0.10 & 0.05 & 1.3 & 0.03 & 6.5 & 67 \\
\hline Caloundra Sth. & Inside & 1,040 & 107 & 2,984 & 29.5 & 3,120 & 3 \\
\hline \multirow[t]{3}{*}{ Hamilton Nth. } & Whole & 0.68 & 0.40 & 8.9 & 0.08 & 53.0 & 78 \\
\hline & Inside & 0.75 & 0.41 & 8.9 & 0.08 & 30.2 & 40 \\
\hline & Outside & 0.60 & 0.35 & 2.5 & 0.12 & 22.8 & 38 \\
\hline \multirow[t]{3}{*}{ Gr. Flagstone } & Whole & 14.4 & 2.02 & 3,723 & 0.28 & 8,900 & 614 \\
\hline & Inside & 193.5 & 4.02 & 3,723 & 0.28 & 6,384 & 33 \\
\hline & Outside & 4.3 & 2.02 & 293 & 0.40 & 2,501 & 581 \\
\hline \multirow[t]{3}{*}{ Ripley Valley } & Whole & 10.5 & 0.8 & 210 & 0.22 & 2,270 & 212 \\
\hline & Inside & 16.3 & 10.5 & 210 & 0.22 & 1,134 & 67 \\
\hline & Outside & 7.9 & 0.5 & 110 & 0.40 & 1,136 & 145 \\
\hline \multirow[t]{3}{*}{ Yarrabilba } & Whole & 31.6 & 4.02 & 2,015 & 1.8 & 3,056 & 96 \\
\hline & Inside & 255.8 & 3.24 & 2,015 & 1.8 & 2,046 & 8 \\
\hline & Outside & 11.4 & 4.02 & 288 & 1.9 & 1,010 & 88 \\
\hline \multirow[t]{3}{*}{ Whole sample } & Whole & 14.6 & 1.8 & 3,723 & 0.03 & 17,351 & 1,192 \\
\hline & Inside & 46.3 & 0.3 & 3,723 & 0.03 & 12,675 & 274 \\
\hline & Outside & 5.1 & 2.0 & 293 & 0.03 & 4,676 & 918 \\
\hline
\end{tabular}

Areas are totals for the sample of properties that met our criteria for entry into the data set, not the whole ULDA declared areas.

In Table 3 we see some of the key distinctions between the characteristics of land owners who own land parcels inside and outside the ULDA declared areas. Corporate ownership is far more common within rezoned areas, as are other connectivity characteristics we capture in our data. Industry group members owned almost $40 \%$ of the rezoned area combined, but only $1.2 \%$ of the comparable areas outside rezoned areas. Critically, lobbyists appear to be extraordinarily effective at ensuring land is rezoned, with no Queensland lobbyist clients owning lots that fell outside rezoned areas while lobbyist clients owned around $30 \%$ of the rezoned land $[16$

In terms of the political connectivity network variables, we see that those in the main component of the network own very little of the outside area $(3.9 \%)$ but much of the inside area $(41.2 \%)$. Similarly, those with above-median (above zero) closeness connectivity own $75.4 \%$ of the inside land area, and only $12.2 \%$ of the outside land area, with a similar pattern for betweenness centrality ( $40.9 \%$ inside land and $2.5 \%$ of outside land in the sample). Landowners we classify as rent-seekers bought land inside ULDA areas on average 7 years prior to rezoning, compared to 10 years on average for other landowners.

\footnotetext{
${ }^{16}$ Only one lobbyist client land owner had a portion of their land outside the area, and that portion is included in the area share in Table 3
} 
Table 3: Summary of land ownership characteristics

\begin{tabular}{lrrrrrrr}
\hline \hline & Mean lot & \multicolumn{2}{c}{ \% of Sample } & \multicolumn{2}{c}{ \% of Inside } & \multicolumn{2}{c}{ \% of Outside } \\
& size (Ha) & Owners & Area & Owners & Area & Owners & Area \\
\hline Corporate & 59.9 & 14.9 & 0.55 & 40.6 & 75.3 & 8.4 & 12.5 \\
Asso'n / Union / Trust & 3.0 & 1.1 & 0.2 & 2.9 & 0.3 & 0.7 & 0.1 \\
Individual & 7.5 & 84.3 & 17.8 & 57.0 & 24.5 & 91.1 & 87.5 \\
PCA member & 851 & 0.5 & 29.5 & 2.1 & 39.9 & 0.1 & 1.2 \\
UDIA member & 1,013 & 0.3 & 17.5 & 0.8 & 23.5 & 0.1 & 1.2 \\
Liberal donor & 515 & 0.9 & 29.7 & 3.3 & 40.1 & 0.2 & 1.4 \\
Labor donor & 468 & 1.0 & 29.7 & 3.3 & 40.1 & 0.3 & 1.4 \\
Any Donor & 368 & 1.2 & 29.7 & 4.1 & 40.1 & 0.4 & 1.5 \\
Lobbyist Client (Qld) & 565 & 0.8 & 29.3 & 3.7 & 39.7 & $0 *$ & 1.2 \\
Lobbyist Client (Any) & 465 & 1.0 & 29.5 & 4.1 & 40.0 & 0.1 & 1.2 \\
In main component & 96.6 & 4.9 & 31.1 & 13.5 & 41.2 & 2.6 & 3.9 \\
Closeness cent. $>$ 0 & 59.2 & 15.0 & 58.4 & 40.6 & 75.4 & 8.1 & 12.2 \\
Betweenness cent. $>0$ & 311.6 & 1.5 & 30.5 & 5.7 & 40.9 & 0.3 & 2.5 \\
'Rent-seeker* & 58.6 & 15.2 & 58.4 & 40.9 & 75.4 & 8.2 & 12.2 \\
\hline \hline
\end{tabular}

Total sample size is 1,137 .

* Defined here as a landowner that exhibits any positive values for rent-seeking activities; either being the main component of the relationship network, having a closeness centrality $>0$, having a betweenness centrality $>0$, or being a lobbyist client or political donor.

\subsection{Land owner characteristic correlations}

We then look at the correlations between various land owner characteristics including those derived from this relationship network in Table 4. We see that most of the landowner characteristic variables show a high degree of correlation with each other, even more so than with the rezoning indicator variable in the bottom row. Liberal party donations, though only a characteristic of ten of the 1,137 land owners, highly predict whether a land owner is also a) a Labor party donor, b) a client of a professional lobbyists, c) a member of the PCA industry group, or d) a part of the main component of the corporate network. Political donations are often regarded as ideologically motivated, yet we see in this data a pragmatic hedging strategy adopted by landowners who donate to politics: seven out of the 14 political donors donate to both sides of politics, and donations to both sides of politics are equally correlated with rezoning success, which is unexpected in light of the long term political dominance of Labor at the time.

Some of the correlations between the variables are not surprising when understood in the context of the methods used to assemble the data. For example, the corporate network is produced by using edges from common membership of industry groups. Hence, the high correlation between PCA membership and membership of the main connected component of the network should be expected, since a large proportion of the relationships (edges) in the main component of the network arise from common membership of the PCA. The same logic applies to the relationship between lobbyist clients and the main component variable.

We highlight in Table 4 the very low correlation (0.07) between whether the land owner is a 
Table 4: Correlation matrix for variables of interest

\begin{tabular}{l|cccccccccc|c}
\hline \hline & $\begin{array}{c}\text { Liberal } \\
\text { Donor }\end{array}$ & $\begin{array}{c}\text { Labor } \\
\text { Donor }\end{array}$ & $\begin{array}{c}\text { Lobby. } \\
\text { Client }\end{array}$ & $\begin{array}{c}\text { PCA } \\
\text { Mem. }\end{array}$ & $\begin{array}{c}\text { UDIA } \\
\text { Mem. }\end{array}$ & $\begin{array}{c}\text { Main } \\
\text { Comp. }\end{array}$ & $\begin{array}{c}\text { Close. } \\
\text { Cent. }\end{array}$ & $\begin{array}{c}\text { Betw. } \\
\text { Cent. }\end{array}$ & $\begin{array}{c}\text { Land } \\
\text { Size }\end{array}$ & $\begin{array}{c}\text { Ln(L. } \\
\text { Size) }\end{array}$ & $\begin{array}{c}\text { Inside } \\
\text { Share }\end{array}$ \\
\hline Liberal & 10 & & & & & & & & & & \\
Labor & $\mathbf{0 . 6 6}$ & 11 & & & & & & & & \\
Lobby. & 0.38 & 0.27 & 11 & & & & & & & \\
PCA & $\mathbf{0 . 6 4}$ & $\mathbf{0 . 6 1}$ & 0.24 & 6 & & & & & & \\
UDIA & 0.36 & 0.17 & 0.17 & 0.23 & 3 & & & & & \\
Main & 0.33 & 0.23 & 0.39 & 0.32 & 0.23 & 56 & & & & \\
Close. & 0.08 & 0.15 & 0.07 & 0.06 & 0.04 & 0.10 & All & & & \\
Betw. & $\mathbf{0 . 5 6}$ & $\mathbf{0 . 5 0}$ & 0.48 & $\mathbf{0 . 6 6}$ & 0.45 & 0.27 & 0.05 & All & & \\
Land & 0.11 & 0.10 & 0.28 & 0.38 & 0.32 & 0.12 & 0.07 & 0.62 & All & \\
Ln(L) & 0.12 & 0.12 & 0.08 & 0.12 & 0.06 & -0.02 & -0.20 & 0.17 & 0.31 & All & \\
\hline Inside & 0.12 & 0.12 & 0.16 & 0.11 & 0.06 & 0.20 & 0.32 & 0.11 & 0.12 & -0.19 & 243 \\
\hline \hline
\end{tabular}

$\mathrm{N}=1,137$. Diagonals are counts of non-zero variables,

Darker highlighted cells show variables highly correlated with rezoning but not each other.

Bold indicates correlation coefficient greater than 0.50 .

lobbyist client, and the closeness centrality of the land owner. It is somewhat surprising that these variables are uncorrelated, since connections to lobbyists, and as a consequence, to other clients of that lobbyist, is one input into the generation of the network. It lends weight to the idea that employing a professional lobbyist is a substitute to being well connected oneself.

\subsection{Land owner rezoning success}

We now turn to the results for the estimations of Equation 1 in Table 5 , which includes five model variations for the construction of $\mathrm{PolC}_{i}$. Outside of owner characteristics, land size is an important factor in determining rezoning success, but in a non-linear way. Extremely large land lots are highly predictive of successful rezoning, though at the lower end of the land size spectrum, the relationship between land size and successful rezoning is reversed. We caution that our land size variable may pick up part of the effect of political connectivity in that those who know that they can change rezoning decisions buy very large plots, or 'land banks', strategically on the urban fringe. Differences in lot sizes might also pick up artefacts of our sampling methodology; plots outside the zoning border to the next barrier (waterway/highway) are relatively smaller, something we need to control for. Thus we are likely to underestimate the full effect of political connectivity by controlling for land area.

Comparing Model 1 to Model 2, we can see that the inclusion of political donations and industry group membership increases the size of the lobbyist client coefficient from 0.23 to 0.38 , indicating that employing lobbyists and direct donations or industry group membership are not complements (collinear), but are more likely to be substitute methods for gaining political favour. However, the large standard errors of the coefficients for each industry group and political donation type in Model 2 arise partly of due to the high collinearity of these variables in the dataset, which is evident in the Table 4 correlation matrix.

Model 3 looks to overcome the collinearity of the political donations and industry group member- 
Table 5: Models of rezoning success

\begin{tabular}{|c|c|c|c|c|c|}
\hline Share of land inside & Model 1 & Model 2 & Model 3 & Model 4 & Model 5 \\
\hline \multirow[t]{2}{*}{ Labor donor } & & 0.08 & & & 0.05 \\
\hline & & $(0.18)$ & & & $(0.18)$ \\
\hline \multirow[t]{2}{*}{ Liberal donor } & & 0.16 & & & 0.10 \\
\hline & & $(0.16)$ & & & $(0.16)$ \\
\hline \multirow[t]{2}{*}{ Any donor } & & & 0.04 & & \\
\hline & & & $(0.12)$ & & \\
\hline \multirow[t]{2}{*}{ Lobbyist client } & $0.23^{*}$ & $0.38^{* * *}$ & $0.22^{*}$ & & $0.37^{* * *}$ \\
\hline & $(0.12)$ & $(0.12)$ & $(0.12)$ & & $(0.14)$ \\
\hline \multirow[t]{2}{*}{ PCA member } & & -0.08 & & & 0.16 \\
\hline & & $(0.21)$ & & & $(0.23)$ \\
\hline \multirow[t]{2}{*}{ UDIA member } & & -0.13 & & & 0.02 \\
\hline & & $(0.23)$ & & & $(0.24)$ \\
\hline \multirow[t]{2}{*}{ Any industry group } & & & -0.06 & & \\
\hline & & & $(0.16)$ & & \\
\hline \multirow[t]{2}{*}{ Main component } & $0.20^{* * *}$ & & & $0.25^{* * *}$ & $0.19^{* * *}$ \\
\hline & $(0.05)$ & & & $(0.05)$ & $(0.06)$ \\
\hline \multirow[t]{2}{*}{ Closeness centrality } & $0.26^{* * *}$ & & $0.26^{* * *}$ & $0.26^{* * *}$ & $0.25^{* * *}$ \\
\hline & $(0.04)$ & & $(0.04)$ & $(0.04)$ & $(0.04)$ \\
\hline \multirow[t]{2}{*}{ Betweenness cent. } & & & & -0.004 & $-0.01^{* *}$ \\
\hline & & & & $(0.002)$ & $(0.00)$ \\
\hline \multirow[t]{2}{*}{$\operatorname{Ln}($ area $)$} & $-0.05^{* * *}$ & $-0.07^{* * *}$ & $-0.05^{* * *}$ & $-0.05^{* * *}$ & $-0.05^{* * *}$ \\
\hline & $(0.01)$ & $(0.01)$ & $(0.01)$ & $(0.01)$ & $(0.01)$ \\
\hline \multirow[t]{2}{*}{$\operatorname{Ln}(\text { area })^{2}$} & $0.02^{* * *}$ & $0.03^{* * *}$ & $0.02^{* * *}$ & $0.02^{* * *}$ & $0.02^{* * *}$ \\
\hline & $(0.00)$ & $(0.00)$ & $(0.00)$ & $(0.00)$ & $(0.00)$ \\
\hline$R^{2}$ & 0.24 & 0.21 & 0.24 & 0.24 & 0.25 \\
\hline
\end{tabular}

Standard errors in parentheses below coefficients. $\mathrm{N}=1,137$

$p$ values $^{*}<0.10,{ }^{* *}<0.05,{ }^{* * *}<0.01$

ship patterns by combining all donor relations into a single variable, and likewise for all industry group members, as well as removing the main component variable that is correlated with industry group membership. This does not reveal any reduction in standard errors for industry group (coeff. -0.6 , s.e. 0.16 ) and donor (coeff. 0.04, s.e. 0.12) variables, suggesting that it is not a raw characteristic of being in an industry group that is advantageous, but how that membership translates to positional gains in the broader relationship network.

Model 4 includes only variables capturing positional characteristics of the relationship network. The coefficients change little from Model 1 with the removal of the lobbyist client variable and the inclusion of the betweenness centrality variable, confirming previous suggestions in the data that employing a lobbyist is a substitute for advantageous position in the relationship network in terms of being connected to the main component, and in terms of closeness centrality (how well connected to each other your own connections are). Betweenness centrality shows a small negative coefficient, which is significant at the $5 \%$ level in Model 5 , but that is suggestive of a minor role, if any, of this type of positioning in the relationship network for gaining political 
favours in our setting.

The picture emerging from these models is that one's position in the relationship network is the underlying mechanism that allows for implicit favouritism, and that political donations may be of secondary importance in that they are mostly a way of signalling loyalty in order to improve one's relationships. In general we see closeness centrality, reflecting the Coleman (1990) view of social capital, as a key mechanism at play in predicting favours in the Queensland property industry.

\subsection{Rent transfer}

To estimate the value of the rent-transfer from ULDA rezoning decisions, we estimate the price model of Equation 2 over a number of leads and lags and summarise the results in Table 6. Since there are only a few sales in some years, the errors around the $a$ and $b$ coefficients of the $W$ and $L$ dummy variable are quite large. All models have high explanatory power, with an $R^{2}$ of around 0.90 , and consistent directional estimates of $a$ and $b$ coefficient through all time periods. The general interpretation from this exercise is that land prices increased more rapidly for land inside the ULDA boundaries, with a particularly large change immediately following the rezoning, reflecting the value of increased possible development density. For clarity, we present this analysis graphically in Figure 5, showing deviation from predicted price paths estimated due to the $W$ and $L$ dummy variables.

Table 6: Price model

\begin{tabular}{lrrrrr}
\hline \hline Ln(price/hectare) & Model 1 & Model 2 & Model 3 & Model 4 & Model 5 \\
& Three yrs & Two yrs & Year prior & Declaration & Year after \\
\hline Time & $1.05^{* * *}$ & $1.07^{* * *}$ & $1.04^{* * *}$ & $0.95^{* *}$ & $0.92^{* *}$ \\
& $(0.40)$ & $(0.40)$ & $(0.40)$ & $(0.40)$ & $(0.39)$ \\
Bris. house price index & $1.08^{* * *}$ & $1.06^{* * *}$ & $1.10^{* * *}$ & $1.15^{* * *}$ & $1.17^{* * *}$ \\
& $(0.18)$ & $(0.18)$ & $(0.17)$ & $(0.16)$ & $(0.16)$ \\
Vendor relationship & $-0.60^{* * *}$ & $-0.61^{* * *}$ & $-0.61^{* * *}$ & $-0.62^{* * *}$ & $-0.60^{* * *}$ \\
& $(0.09)$ & $(0.09)$ & $(0.09)$ & $(0.09)$ & $(0.09)$ \\
Declared inside dummy $(a)$ & $0.19^{*}$ & $0.27^{* *}$ & $0.29^{* *}$ & 0.36 & $0.94^{* * *}$ \\
& $(0.11)$ & $(0.12)$ & $(0.13)$ & $(0.23)$ & $(0.32)$ \\
Declared outside dummy $(b)$ & 0.06 & 0.07 & 0.04 & 0.15 & 0.12 \\
& $(0.07)$ & $(0.08)$ & $(0.09)$ & $(0.14)$ & $(0.16)$ \\
\hline$R^{2}$ & 0.91 & 0.91 & 0.91 & 0.91 & 0.91 \\
$\mathrm{~N}$ & 822 & 822 & 822 & 822 & 822 \\
$\mathrm{~N}$, inside dummy, $W=1$ & 47 & 35 & 27 & 8 & 4 \\
$\mathrm{~N}$, outside dummy, $L=1$ & 151 & 151 & 75 & 26 & 16 \\
\hline \hline
\end{tabular}

Dependent variable for each $i \operatorname{lot}$ is $\ln \left(\frac{p_{i t}}{a_{i}}\right)$. Standard errors in parentheses below coefficients.

All models include dummy variables of each ULDA area, and control for $\operatorname{Ln}\left(\right.$ area) and $\operatorname{Ln}(\text { area })^{2}$.

One might wonder why the price of the areas does not increase immediately in the year of declaration. This is partially by construction of how the ULDA worked, in that they did not 


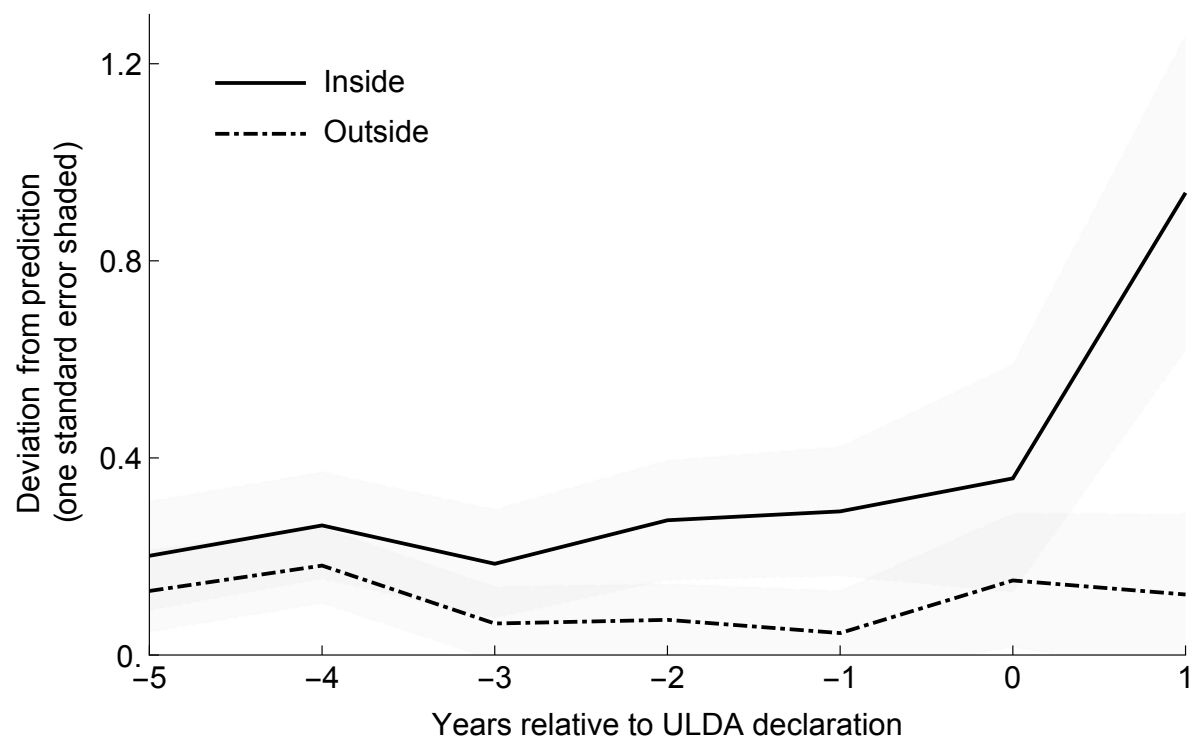

Figure 5: Deviation from predicted price for land inside and outside ULDA areas

merely rezone the areas but also provided a conduit for land re-use permissions to those who owned properties inside the zone. Hence the property developers who bought land may have used their connections to get favourable permissions, selling the redeveloped land in future years. This is probably why the price increase is so pronounced in the year after the declaration as it denotes the moment at which there is true resale to the general public.

Using these regression results, we are able to estimate the size of the rent transfer to land owners in the ULDA areas using Equation 3 . We use the one year lag results from Table 6 as most likely to reflect the cumulative gains from this rezoning decision,

We estimate the gains in terms of economic rent transferred to land owners within the ULDA areas, $R$ to be $\$ 710$ million (or $\$ 56,000$ per hectare) of which the 100 land owners who qualify as rent-seekers as per Table 3 captured $\$ 410$ million, or $56 \%$ if the total rents allocated due to owning $75 \%$ of the rezoned land. In contrast, by the same rent-seeking classification we use, such land owners held only $12 \%$ of land outside rezoned areas. The marginal gains to political connectivity, as per Equation 4 and using $\hat{\gamma}$ estimates from the Model 5 implementation of $\mathrm{PolC}_{i}$, is $\$ 190$ million. We consider this as a return for land owners from becoming connected to the relationship network in the case of the ULDA rezoning in Queensland, i.e. the gain of becoming connected over and above merely 'being in the game' and thus speculating on property rezoning without being connected.

\section{Discussion and conclusion}

In this paper we utilised a unique regulatory change in Queensland, Australia, that allows us to disentangle the political intention to rezone as a growth imperative from the politics of precisely where the rezoning takes place. Following a prior decision to coordinate large scale regional rezoning, the state of Queensland decided in 2007 to create a new institution that would decide 
on the precise areas to be rezoned, which in reality turned out to have little bearing on the intended rezoning areas that followed previous technical assessments, such as suitability and accessibility. This allows us to look at the importance of the political connectivity of the various landowners in getting favourable rezoning decisions and hence obtaining a valuable new property right.

We combined a number of disparate datasets in order to compile a relationship network containing connections deemed relevant to supporting the allocation of mutual favours within a network, and showed that the network characteristics of land owners strongly determined rezoning success. Being in the main component of the relationship network increases the chance of favourable rezoning by $19 \%$, while improving one's network position in terms of closeness centrality offers a $25 \%$ increase in the chance of rezoning success. Network variables provided far greater explanatory power of rezoning decisions than more simple observable characteristics, such as political donations and being a member of an industry group; showing that it matters to have information on the whole network of relations rather than simply binary indicators of political connectedness. Yet, our network measures were still not able to capture many direct links to politicians because such information is not publicly available, meaning that our results are probably an underestimate of the true importance of political connectivity. For example, records of politicians' family members are not widely and consistently available, yet previous research suggest that such connections are highly valuable in sub-national politics even in low corruption countries (Amore \& Bennedsen, 2013).

Using land sales data we estimate that the value of the additional development rights granted by the ULDA declarations is $\$ 710$ million, of which $\$ 410$ million was captured by land owners we are able to classify as rent-seekers; that is, land owners who exhibit some degree of connectedness in our observable relationship network. At the margin, the gains to becoming connected in our scenario is estimated to be $\$ 190$ million.

While the scale of the value transfer from this process may appear modest in relation to aggregate wealth in cities in Queensland, we must keep in mind that this represents a tiny sample of planning activities Statewide. Indeed, we have investigated just a $12,675 \mathrm{Ha}$ sample of single planning decision, much of which remains relatively low value land on the urban-rural boundary. Given the additional historical evidence in Section 3.2, the thousands of rezoning decisions over the last decades are likely to be an avenue for allocating many billions of dollars in development rights to connected land owners annually across the country.

Our results are consistent with a number of previous estimates of the payoff to political connections and returns to social capital (Faccio et al. ,2006, Cingano \& Pinotti, 2013, Bertrand et al. I, 2011; Engelberg et al. , 2012; Hillman, 2005, Faccio et al. , 2006; Chen et al. , 2011; You \& Du, 2012). Where we differ is that we do not look at specific relationships to politicians, but the nature of positions within a larger network of relationships which reflects a broader view of social capital. We find that it is more important to be part of a close-knit group that all have strong ties with each other, i.e. to have 'closeness centrality' (a concept due to Coleman (1990)), than it is to bridge many different groups. Specialisation of relations matters more for getting favourable rezoning than knowing lots of people. Corruption investigations by media and state prosecutors suggest that the actual quid pro quo mechanism works via a revolving door where property developers and the key political/bureaucratic positions are the same people, exchanging positions over time. Employing professional lobbyists, who are effectively selling their own advantageous position in the relationship network, appears a substitute to this revolving door.

Whilst we cannot say for certain whether the rezoning decisions imply efficiency losses, rather 
than just representing an economic transfer from the population to connected land owners, we can note that the rezoned areas are highly disjointed and irregularly shaped, not what one would expect from an efficiency point of view (see the rezoning areas in Figure A.1 of the Appendix). The rezoning decision clearly appears to have incurred efficiency losses as the eventual rezoned areas were very different from the previously announced areas that councils were forced to plan for, incurring unnecessary expenses.

From a standard economic point of view, rezoning transfers new property rights from the community to specific individuals; rights that could be priced in a market rather than allocated politically and incurring the associated costs of rent-seeking. One option for pricing rezoning decisions is to tax either the increased value of land (a betterment tax), tax land values completely (a 100\% land value tax), or sell additional development rights to land owners through a local auction process. Alternatively, democratic mechanisms for directly deciding new development areas could allow for competing interests to be better balanced, and perhaps also ultimately lead to pricing of rezoning decisions. While much research remains to be done to see just how these options might be implemented in Australia and elsewhere, the same relationship networks that allow current favouritism to thrive in rezoning decisions will surely hinder any systematic reform of the rezoning process. 


\section{References}

Amore, Mario Daniele, \& Bennedsen, Morten. 2013. The value of local political connections in a low-corruption environment. Journal of Financial Economics, 110(2), 387-402.

Bertrand, Marianne, Bombardini, Matilde, \& Trebbi, Francesco. 2011 (February). Is It Whom You Know or What You Know? An Empirical Assessment of the Lobbying Process. Working Paper 16765. National Bureau of Economic Research.

Brass, Daniel J., Butterfield, Kenneth D., \& Skaggs, Bruce C. 1998. Relationships and Unethical Behavior: A Social Network Perspective. Academy of Management Review, 23(1), 14-31.

Burt, Ronald S. 1995. Structural Holes: The Social Structure of Competition. Harvard University Press.

Burt, Ronald S. 2000. The network structure of social capital. Research in Organizational Behavior, 22, 345-423.

Calabrese, Stephen, Epple, Dennis, \& Romano, Richard. 2007. On the political economy of zoning. Journal of Public Economics, 91(1), 25-49.

Callinan, Rory. 2012. Conflicting explanations over council property deal. Brisbane Times, March 2.

Chai, Sun-Ki, \& Rhee, Mooweon. 2010. Confucian Capitalism and the Paradox of Closure and Structural Holes in East Asian Firms. Management and Organization Review, 6(1), 5-29.

Chen, Charles J.P., Li, Zengquan, Su, Xijia, \& Sun, Zheng. 2011. Rent-seeking incentives, corporate political connections, and the control structure of private firms: Chinese evidence. Journal of Corporate Finance, 17(2), 229 - 243.

Cingano, Federico, \& Pinotti, Paolo. 2013. Politicians at work: The private returns and social costs of political connections. Journal of the European Economic Association, 11(2), 433-465.

CMC. 2009. Allegation against the Honourable TM Mackenroth in respect of land at Elimbah East: A report from the CMC. Tech. rept. Crime and Misconduct Commission Queensland.

Coleman, James S. 1990. Foundations of Social Theory. Harvard University Press.

Dassen, Adrie. 2010. Networks: Structure and action: Steering in and steering by policy networks. University of Twente.

De Figueiredo, John M, \& Richter, Brian Kelleher. 2013. Advancing the empirical research on lobbying. Tech. rept. National Bureau of Economic Research.

Dehring, Carolyn A., Depken II, Craig A., \& Ward, Michael R. 2008. A direct test of the homevoter hypothesis. Journal of Urban Economics, 64(1), 155-170.

DIP. 2007. Queensland Housing Affordability Strategy. Tech. rept. Department of Infrastructure and Planning, Queensland Government.

Dodson, Jago, Coiacetto, Eddo, \& Ellway, Claire. 2006. Corruption in the Australian Land Development Process: Identifying a research agenda. In: Second National Conference on the State of Australian Cities.

Durlauf, Steven N. 2002. On the Empirics of Social Capital. The Economic Journal, 112(483), F459-F479. 
Engelberg, Joseph, Gao, Pengjie, \& Parsons, Christopher A. 2012. Friends with money. Journal of Financial Economics, 103(1), 169 - 188.

Engle, Robert, Navarro, Peter, \& Carson, Richard. 1992. On the theory of growth controls. Journal of Urban Economics, 32(3), 269-283.

Faccio, Mara. 2006. Politically Connected Firms. The American Economic Review, 96(1), 369386.

Faccio, Mara, Masulis, Ronald W., \& McConnell, John J. 2006. Political Connections and Corporate Bailouts. The Journal of Finance, 61(6), 2597-2635.

Fischer, Manuel. 2013. Policy network structures, institutional context, and policy change. Tech. rept. Compasss Working Paper 73.

Fisman, Raymond. 2001. Estimating the Value of Political Connections. The American Economic Review, 91(4), 1095-1102.

Grabowski, Richard. 2013. The formation of growth coalitions: the role of the rural sector. Journal of Institutional Economics, 9(3), 329-350.

Granovetter, Mark. 1985. Economic Action and Social Structure: The Problem of Embeddedness. American Journal of Sociology, 91(3), 481-510.

Granovetter, Mark. 2005. The Impact of Social Structure on Economic Outcomes. The Journal of Economic Perspectives, 19(1), 33-50.

Gray, Stephen, Harymawan, Iman, \& Nowland, John. 2014. Political and government connections on corporate boards in Australia: Good for business? Australian Journal of Management, 124.

Hele, Michelle, \& Stolz, Greg. 2006. Claims of Devine intervention. The Courier Mail, November 28. http://www.couriermail.com.au/news/queensland/claims-of-devine-intervention/storye6freoof-1111112601396.

Hilber, Christian A. L., \& Robert-Nicoud, Frédéric. 2013. On the origins of land use regulations: Theory and evidence from US metro areas. Journal of Urban Economics, 75(0), 29-43.

Hillman, Amy J. 2005. Politicians on the Board of Directors: Do Connections Affect the Bottom Line? Journal of Management, 31(3), 464-481.

Howlett, Michael. 2002. Do Networks Matter? Linking Policy Network Structure to Policy Outcomes: Evidence from Four Canadian Policy Sectors 1990-2000. Canadian Journal of Political Science, 35(02), 235-267.

Jackson, Matthew O, Rodriguez-Barraquer, Tomas, \& Tan, Xu. 2012. Social Capital and Social Quilts: Network Patterns of Favor Exchange. The American Economic Review, 102(5), 18571897.

Jackson, Michael, \& Smith, Rodney. 1995. Everyone's doing it! Codes of ethics and New South Wales parliamentarians' perceptions of corruption. Australian Journal of Public Administration, 54(4), 483.

Lubell, Mark, Feiock, Richard C., \& Ramirez, Edgar. 2005. Political Institutions and Conservation by Local Governments. Urban Affairs Review, 40(6), 706-729. 
Mackenroth, Terry. 2004. Draft South East Queensland Regional Plan. Tech. rept. Office of Urban Management.

McCutcheon, Peter. 2009 (July). Queensland returning to dark corrupt past. 7:30 Report, Australian Broadcasting Corporation. Broadcast 29 July 2007.

Molotch, Harvey. 1976. The City as a Growth Machine: Toward a Political Economy of Place. American Journal of Sociology, 82(2), 309-332.

Newman, M E J. 2006. Modularity and community structure in networks. Proceedings of the National Academy of Sciences of the United States of America, 103(23), 8577-8582.

Robertson, Chris. 2011. Queensland's Urban Land Development Authority - White Knight or simply another Planning Layer of complexity? M.Phil. thesis, University of Queensland.

Schone, Katharina, Koch, Wilfried, \& Baumont, Catherine. 2013. Modeling local growth control decisions in a multi-city case: Do spatial interactions and lobbying efforts matter? Public Choice, 154(1-2), 95-117.

Simon, Guy, \& Henneberry, John. 2000. Understanding urban development processes: Integrating the economic and the social in property research. Urban Studies, 37(13), 2399-2416.

Sobel, Joel. 2002. Can We Trust Social Capital? Journal of Economic Literature, 40(1), 139-154.

Solé-Ollé, Albert, \& Viladecans-Marsal, Elisabet. 2012. Lobbying, political competition, and local land supply: Recent evidence from Spain. Journal of Public Economics, 96(1-2), 10-19.

Solé-Ollé, Albert, \& Viladecans-Marsal, Elisabet. 2013. Do political parties matter for local land use policies? Journal of Urban Economics, 78(0), 42-56.

Sparrowe, Raymond T., Liden, Robert C., Wayne, Sandy J., \& Kraimer, Maria L. 2001. Social Networks and the Performance of Individuals and Groups. The Academy of Management Journal, 44(2), 316-325.

Strom, Elizabeth. 1996. In Search of the Growth Coalition: American Urban Theories and the Redevelopment of Berlin. Urban Affairs Review, 31(4), 455-481.

Svendsen, G.T., \& Svendsen, G.L.H. 2009. Handbook of Social Capital : The Troika of Sociology, Political Science and Economics.

Terhorst, Pieter, \& Van De Ven, Jacques. 1995. The national urban growth coalition in The Netherlands. Political Geography, 14(4), 343-361.

The Sunday Mail. 2008. Queensland's richest 100. The Courier Mail, August 31.

Wardill, Steven, \& Helbig, Koren. 2011. Campbell Newman seeks advice from Integrity Commission after failing to declare wife's property portfolio. The Courier Mail, September 20.

Williams, Robert. 1999. Democracy, development and anticorruption strategies: Learning from the Australian experience. Commonwealth \& Comparative Politics, 37(3), 135-148.

You, Jiaxing, \& Du, Guqian. 2012. Are Political Connections a Blessing or a Curse? Evidence from CEO Turnover in China. Corporate Governance: An International Review, 20(2), 179194. 


\section{Appendix}

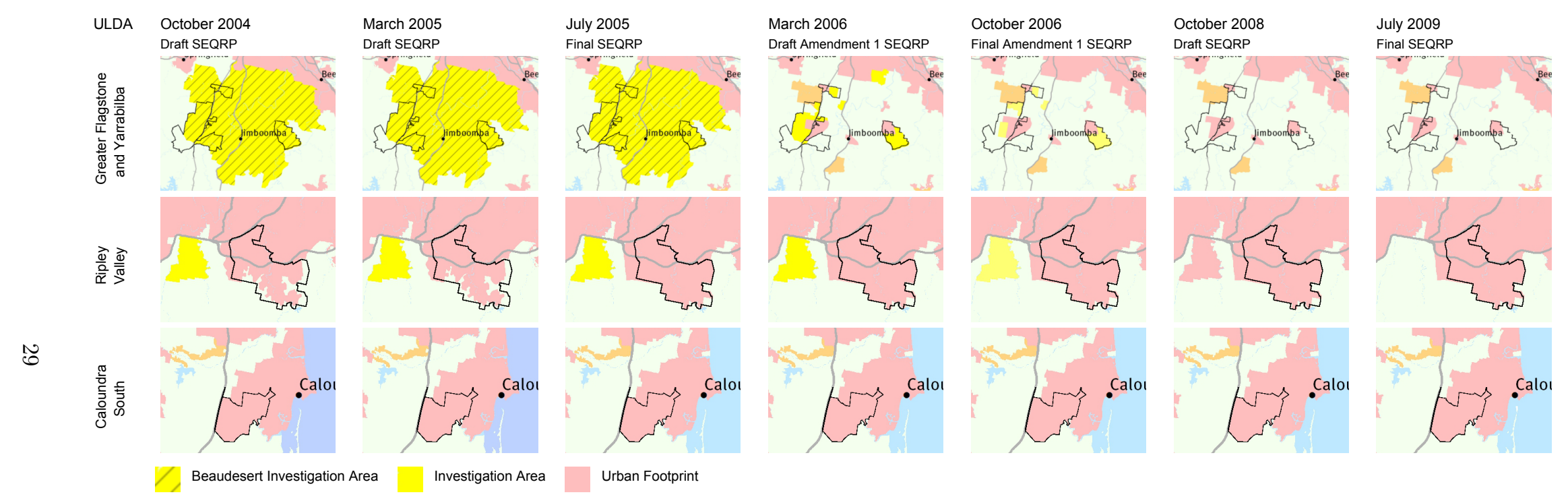

Figure A.1: Comparison of SEQRP (shaded areas) and ULDA areas (bold outline, Yarrabilba is right side area of top panels) 


\section{Yarrabilba Planning Application Process 2003 - 2010 (Pre-ULDA)}



Figure A.2: Copy of Lend Lease document with timeline of planning amendments sought for Yarrabilba 